\title{
Clinical Legal Education Revisited
}

\author{
Richard Lewis
}

\section{Professor of Law, Cardiff University, Wales, United Kingdom ${ }^{1}$}

In this article I return to a question which was of considerable interest to me and several other colleagues when I first became a law teacher in the UK in 1974. That question was: "Should a law school try to teach students in a legal clinic where they are have to deal with problems faced by real clients?" The use of the word 'clinic' prompts the analogy of trainee doctors meeting real patients in their medical clinics. It is difficult to conceive of a doctor qualifying without ever examining a living body, or of scientists completing their education without setting up practical tests - but this has been the norm in university legal education outside of North America. Why should this be so? In this article do two things: first, I reflect upon new factors - as well as the old considerations - which affect the answer to the question of whether clinical education should have a place in law school teaching; and secondly, I explain why that question is of growing importance not only in the UK but also in other countries.

The subject should be of particular interest in countries, such as Japan, where fundamental reconsideration is taking place of how lawyers are to be trained and for what purposes. Although clinical legal education is only one way in which theory and practice can be brought together, it encapsulates many of the issues in the reform debate. Views expressed on this subject may determine not only the future character of university legal education, but also the nature and scope of the legal profession itself. Clinical legal education thus constitutes a case study of many of the major issues in legal education.

\footnotetext{
${ }^{1}$ Cardiff Law School, Cardiff University, PO Box 427, Cardiff, CF1 1XD, Wales, UK. Email - LewisRK@cardiff.ac.uk
} 
A little personal history may help to place this article in context. Let me describe my experience of studying law as an undergraduate in order to explain how I first came to be interested in clinical education. I do this for two reasons: in order to reveal what I think was a common experience of UK law students of my generation, and to put a little flesh on what otherwise might be the dry bones of educational theory. I am aware that it can be dangerous to rely upon personal experience in order to formulate general views, but here I am prepared to take that chance.

I graduated from Oxford University in 1972 frustrated by my three years study of law. In common with many students entering university I had thought that I would be embarking on a "relevant" course of study - encountering laws, processes and personnel related to my personal experience of the scope and impact of the legal system. In short, I thought that my studies would, to an extent, reflect my limited knowledge of life derived from the working class community in which I had lived. How wrong this proved to be. There are many examples I could give, but I will limit myself to two:-

- I thought that I would learn something about what powers the police had, and the procedure by which the prosecutions which I read about in my local paper took place. I thought that I would gain some knowledge of the range of criminal laws which protected person and property. However, criminal law, studied for only a very short time, was pre-occupied with the fine distinctions between mental states which affect decisions at the apex of the pyramid of criminal justice system. It had little to say about everyday experience of the criminal process. Its focus on the fine points which sometimes distinguished murder from the lesser charge of manslaughter was not a common problem in my part of the world! The word 'police' was hardly mentioned, and their powers never examined. The criminal justice process and especially what happened as a matter of routine in the lower courts at the base of the pyramid was ignored. How a crime was proven, who decides whether or not to prosecute, where the trial takes place and what pressures there were to plead guilty were never discussed. I soon realised that the law I was studying was very artificial. Dissatisfaction with academic law thus began early in my legal career.

- Contract lawagain was discussed by means of abstract theoretical rules applied to "futile conceptual problems which have no counterpart 
in the world of reality." I knew that climbing a greasy pole in return for a reward which was withdrawn just before the climber reached the top, or shouting a bargain across a noisy river, were not what lawyers were really concerned about. But I was left with very little indication of what the mass of lawyers actually did. Instead I was indoctrinated into the presumptions of classical contract law. ${ }^{3}$ These included the unstated notion that if there is a breach of contract then the automatic remedy is to take legal action. This dangerous fallacy has hindered many an inexperienced lawyer's relationship with prospective business clients. Enforcement of the law once the action had proven successful was also taken for granted. In fact there was no discussion of civil procedure at all - a failing of UK law schools which still continues. Finally, the common concerns voiced by people in my community at home - whether about their experience of the civil law system as consumers or as debtors - were ignored.

It was therefore in spite rather than because of my experience of studying law at university that I went on to complete the vocational stage of legal training. Then, as a trainee, I joined a large company law firm in the City of London. I worked in its corporate merger department. The disdain held by many of the legal practitioners with whom I worked for the education both they and I had received was all too apparent. Whatever limited company law I had learned at the vocational stage of training was soon shown to be irrelevant to the work that was being done. I was told that the City of London Code on Take-overs and Mergers - not then of any legal force - was the guidance that I needed, together with the law firm's own internal precedents and procedures.

In the evenings I assuaged my social conscience by working in a Law Centre offering free legal advice in the East End of London. There I found a very different type of clientele and became even more aware of how little "relevant" law I actually knew. Social security, immigration, labour, consumer law and a host of other areas were, it seemed, not subjects fit to be studied by either an Oxford law student or one passed by the Law Society as ready to become a practitioner. My dissatisfaction with the training I had received

2 P. S. Atiyah, Accidents, Compensation And The Law (1st ed 1970) preface p. xv.

3 One of the first areas which I examined as an academic was contract law teaching and I used empiricism to undermine some of the classical notions then still dominant. See my articles "Criticisms Of The Traditional Contract Course" (1982) 10 Law Teacher 111, and "Contracts Between Businessmen" (1982) $9 \mathrm{~J}$ of Law and Society 153. 
increased.

I left practice - as I thought temporarily - to join the Faculty at Northwestern University in Chicago for a year. I was in charge of the legal writing and moot court programmes. (These responsibilities in themselves have been seen as involving simulations and thus "clinical" education). But I also spent time working in the legal clinic where students, supervised by members of staff, gave legal advice and representation to those too poor to otherwise obtain it. For a variety of reasons the students were much closer to the practice of law than I had ever been as a student. ${ }^{4}$ At the clinic the dedication of the staff, the enthusiasm of the students and the usefulness of the work being done made a lasting impression on me. Although I recognised that the clinical experience could not cure all the ills of the education system I had identified, I thought that it had much to offer.

On returning to the UK I joined the Faculty at Cardiff. It was (and is) a very lively law school. It had a small clinic of sorts - giving advice primarily to students on landlord and tenant, and consumer problems. One of the debates in the 1970's was whether the law school should become more involved with clinical legal education. ${ }^{5}$ For various reasons - some of which I will examine later - it did not do so. Twenty five years on and I now find myself returning to that debate. I think it is one which many law schools will have to face again as we enter this next millennium.

${ }^{4}$ This was taken to unusual lengths. In Chicago, murder is somewhat more common than in the whole of the UK. One of the City's many murder trials was held on law school premises - although it did not involve the legal clinic.

${ }^{5}$ See my former colleague's investigation which informed our debate: W. Rees, "Clinical Legal Education: An Analysis Of The University Of Kent Model" (1975) 9 The Law Teacher 125. For descriptions of law clinics operating in the 1990's see R. Grimes, "Reflections On Clinical Legal Education" (1995) 29 Law Teacher 169 (Sheffield Hallam), and H. Brayne, "Law Students As Practitioners: Developing An Undergraduate Clinical Programme At Northumbria University" in J. Webb and C. Maugham (eds.) Teaching Lawyers' Skills (1996). 


\section{WHAT IS CLINICAL LEGAL EDUCATION?}

Clinical legal education is not a term of art; it can mean different things to different people. It has been defined as:

"a learning environment where students identify, research and apply knowledge in a setting which replicates, at least in part, the world where it is practised.... It almost inevitably means that the student takes on some aspect of a case and conducts this as it would ... be conducted in the real world." 6

However, for present purposes I want to narrow the focus for discussion. This is because in a broad sense 'replicating what goes on in the real world' forms part of much law school teaching and always has done so. It could include a wide variety of activity including, for example:-

(a) Simulations - students can learn from a variety of simulations of what happens in legal practice. For example, moot courts are commonplace. They have traditionally formed part of law school activity and introduce students to the intricacies of advocacy, at least before appella te courts. More ambitiously, use can be made of mock trials, sometimes involving professional actors in order to convey the difficulties of, for example, introducing evidence and establishing facts in what may be the rapidly changing environment of a first instance tribunal. Other simulations ${ }^{7}$ can range from -

$v$ negotiation exercises - whereby opposing groups of students learning the art of negotiation, rather than trial court litigation, by being given realistic case files and asked to resolve them in as economic and fair manner as possible.

$v$ client interviewing exercises - a national competition sponsored by the Law Society was entered by 26 UK Law Schools in 1999, and the international competition was held at the John Marshall Law School in Chicago.

$v$ transaction exercises - between groups of students such as buying or

${ }^{6}$ R. Grimes, "The Theory And Practice Of Clinical Legal Education" in J. Webb and C. Maugham (eds.) Teaching Lawyers' Skills (1996) at p 138.

7 See generally chapter 5 of H. Brayne et al, Clinical Legal Education (1998). They are also described more fully in Marilyn Pilkington article published in this volume "Professional Development Education For Law Students And Lawyers: An Experience In Canada." 
selling property or with individual students in e.g. drafting a will.

$v$ legal writing and drafting programmes of the kind I did at Northwestern University.

Although of exceptional value in teaching law, these simulations can lack the complexity of real client work, and the role play may not create the same demands that exist upon the legal practitioner.

(b) Placements - students can be sent out to work with practising lawyers for short periods to encounter real problems, clients, and courts. They are then expected to bring back their experience to the law school and reflect upon it, using it to inform the remainder of their time spent in the academic establishment. ${ }^{8}$ On the one hand, although placements require the academic institutions to have good relations with law firms and practitioners, they are relatively easy to set up. They are particularly attractive to some law schools because that they can be arranged at little cost. On the other hand, the student's experience can vary greatly, and it is especially difficult for teachers to monitor what has happened in order to make use of it, and provide effective feedback. It is difficult to assess the student's progress.

Although these placements and simulations have been included by some commentators as examples of clinical legal education, here I wish to confine my discussion to a narrower activity. By clinical legal education I refer only to student involvement with real clients in an environment supervised and controlled directly by the law school. The practical experience forms part of, and is integrated within, the education provided by the law school.

\section{THE BENEFITS OF CLINICAL EDUCATION}

There are many benefits which have been claimed to follow from clinical legal education programmes. Only the main ones can be summarised here:-

${ }^{8}$ Pilkington, op cit describes an extensive and very successful programme which operates in Ontario. 


\section{(a) Learning by experience}

The main advantage of clinical education is that, compared to traditional teaching methods, it involves a different approach to the learning of law: it encompasses experiential learning, or "learning by doing." Instead of learning by means of traditional lectures - where students are often expected to be sponges reactively soaking up information - students are much more proactive participants in the learning process. It is their initiative which determines the scope of the client's problem; and they plan and work for its solution. Such students are much more likely to learn if they recognise that their success is determined by their own efforts rather than external factors e.g. how good is the lecturer is, or what questions have previously been asked on the exam paper.

In addition, if there is a clear purpose to what is being learned it is more likely to have an effect. It is not so much what has been learned, but what can be done with what has been learned. That is, it is applying the knowledge that is the key, not the learning of it.

Clinical education clearly gives opportunities for the knowledge to be applied, but it also goes beyond this and calls for reflection and self examination. It gives students the opportunity to explain why they are taking certain actions and they are able to discuss and reconsider their actions. Legal practitioners themselves rarely have the time or opportunity to do this. Students, by contrast, can examine the legal and social issues in some depth, and they can form the basis for looking at the lawyer's role and at legal ethics within a practical context. The result is that what is learned is far more likely to remain with the student than the knowledge crammed for an extremely artificial examination paper.

The contrast between experiential learning and the traditional informationtransmission model of legal education can be stark. Treating students as merely empty vessels into which legal information can be poured - apparently without end - provides them with only a small part of what they need in order to understand the nature and processes of law, and to operate effectively as a 
practitioner. As a result the teaching of legal skills is now widely recognised "as a legitimate, even critical part of an effective legal education." 9

We now have a great deal of knowledge about how students learn. There is a considerable literature on educational theory. It is important for law schools to understand and make effective use of this information when considering how they achieve the educational goals that either are set for them or they set for themselves. All too often in the past law schools have operated as if they alone knew best how to teach and how students learn. That position can no longer be maintained. Reformers of legal education, whether in Japan or elsewhere, must look to the wider developments which have taken place in education generally if they are to set up an effective and modern system for instructing students.

\section{(b) Acquisition of skills}

Experiential learning means moving away from an information-based syllabus caricatured by rote or memory-based learning accompanied by condensed summary examinations. Instead clinical education embraces a skills-based approach. This means paying as much attention to the processes associated with legal practice - e.g. the structure a letter, the interview with the client, face to face negotiation - as to the legal content of the rules forming the background to the work done.

Many of these skills have already been mentioned. ${ }^{10}$ Their importance is specifically examined in the most recent UK government report on legal education. ${ }^{11}$ The skills include:-

${ }^{9}$ J. Macfarlane, "The Legal Skills Movement Ten Years On: Triumph Or Compromise?" (1997) $24 \mathrm{~J}$ Law and Society 440.

10 The range is well illustrated in H. Brayne, The Legal Skills Book (2nd ed 1998).

11 Lord Chancellor's Advisory Committee On Legal Education And Conduct, (ACLEC), First Report On Education and Training (1996) section 2, p. 8. For a robust defence of skills teaching against attacks that it is narrow, anti-intellectual, amoral and unnecessary see Twining, "Legal Skills And Legal Education" (1988) 22 Law Teacher 4. For a view that such teaching is not part of the law school mission see Browsword, "Where Are All The Law 
- Research skill - especially where the relevant area of law is completely new.

- Communication skills - e.g. advocacy before differing tribunals or bodies.

a Interviewing - e.g. clients and witnesses. The law student's traditional indoctrination into a cross examiner's style is revealed in clinical practice as inadequate and often leading to obscuring the facts rather than discovering them. Instead students must learn to relate to clients and e.g. develop active listening skills in order to obtain the full facts.

a Counselling - e.g. helping sometimes bewildered clients to understand and deal with events.

D Drafting-

a Negotiating - the art of 'settlement for something instead of litigating for all' reflects much more the realities of legal practice and the use made of the law than does study of formal accounts of those untypical disputes which are adjudicated by a court.

a Problem solving - seeing the full context of a client's problem and bringing together what otherwise might be seen as distinct areas of legal study - e.g. contract, debt, housing and land law, together with social security and civil procedure commonly arise together in a landlord-tenant dispute.

- Interpersonal and organisational skills - including e.g. communicating and working as a member of a team, helping to organise and maintain office procedures.

\section{(c) Student motivation and development}

Students who work in a legal clinic are enthusiastic about their experience. They are self-motivated and often highly committed to the work. They are more responsible for what they do and how they do it. In theory, the teacher's role becomes more facilitative - helping students discover solutions for themselves. My own disenchantment with law school when a student is a feeling still shared by all too many students. To an extent involvement in clinical work can help reduce such feelings, and can invigorate future study. It can cause students to think again about what law school offers and what direction their future career could take. 
"Clinical experience puts colour in the empty outlines of the legal comic book.... Questions which were dull and meaningless become important and exciting. Answers which seemed black and white become grey, red and green. Dull legal rules become memorable elements of unforgettable events."12

\section{(d) Professional ethics and responsibility}

The study of ethics and the professional responsibility and conduct of lawyers has been markedly absent from law schools in contrast to medical schools. However, there has been a growth of interest in this area in recent years, and it is a subject which arguably is better dealt with in a clinical context where the often abstract notions can be given a practical context. ${ }^{13}$ Whether educators can actually affect the development of student's moral consciousness is much open to debate. ${ }^{14}$ But at least the crucible of the clinic allows moral issues to be debated more openly than within the confines of the traditional curriculum.

\section{(e) Involvement with the local community}

The image of the university as an ivory tower is often all too real in that it can be very divorced from the environment in which it operates. Not only its students but also its staff can be cut off from the local community. A law clinic can help reduce this isolation by making the law school more relevant to that community. It can, for example, offer advice and assistance to local people

\footnotetext{
${ }^{12}$ A. Conard, "Letter From The Law Clinic" (1973) 18(1) University of Michigan Law Quadrangle Notes 18.

13 J. Webb, "Inventing The Good: A Prospectus for Clinical Education And The Teaching Of Legal Ethics In England" (1996) 30 Law Teacher 288, and J. Webb, "Ethics For Lawyers Or Ethics For Citizens? New Directions For Legal Education" (1998) 25 J Law and Society 134.

14 See the doubts expressed in H. Arthurs, "Why Canadian Law Schools Do Not Teach Legal Ethics" in K. Economides, Ethical Challenges To Legal Education And Conduct (1998) at p 105 et seq. But see Professor Choi's article in this volume, "Legal Education In Korea: Towards A Professional Model," in which he suggests that the unethical practices of lawyers in his country are partly the result of the kind of legal education received. He suggests that a broader based approach to legal education might produce a more responsible and ethical legal profession.
} 
who might not otherwise obtain any help at all. The benefits of this can operate in more than one direction. Most obviously, the most disadvantaged members of society may gain some means of redress. But in addition the young student may be faced with the problems of those from a different generation and background. This experience can add to their understanding of the position of others in society, and can increase their maturity and sense of responsibility. They have to deal with problems without becoming so emotionally involved with clients as to have their judgement clouded.

\section{SOME PROBLEMS OF CLINICAL LEGAL EDUCATION}

\section{(a) The integration of the clinic within the law school}

There is a danger that the clinic will become an isolated outpost of the law school, and not absorbed within its mainstream activity. It can be seen by students as an interesting diversion, divorced from the rest of their legal teaching. To avoid this it is important to draw clear links between substantive law courses and work done in the clinic. For example, problems arising in the clinic can be re-examined in other law classes, research can be done on them, and even action recommended. A wide range of teacher involvement is desirable. However, there is no ready-made solution to the problem of integration. ${ }^{15}$

There is a danger that unless the law school embraces the direction in educational philosophy which lies behind the teaching of skills the clinical work will be marginalised and treated as merely providing a "poverty law" service for the community. At its worst this could result in a couple of members of staff being left alone to supervise an ever-expanding indiscriminate caseload, involving but a small clique of students, and where there is no time to discuss, or write about the educational objectives, or about the successes and failures of what has been done. The need for skills teaching to be underpinned by an appreciation of the theoretical framework of

\footnotetext{
${ }^{15}$ H. Brayne et al, Clinical Legal Education (1998) p 258.
} 
education is crucial in the law school's ability to integrate the clinical work. ${ }^{16}$

\section{(b) Staffing problems}

Traditional legal education in the UK has been marked by a sharp contrast between the academic stage (generally a three year course of study at a university), and the vocational stage (a one year course which was left in the hands of the legal profession and in which the university played no part). ${ }^{17}$ Only a small minority of university law teachers were qualified to practice, and very few of these had actually worked as lawyers for any period of time. Asking such teachers to set up a clinical programme at university was therefore beset with problems.

However, this portrait of traditional legal education has now much changed. The profession has given up exclusive control of the vocational stage, and has allowed a number of universities to become involved. Cardiff is one of these institutions which provide skills training by offering a fourth year of legal study at university. We have appointed about twenty new members of staff in the last six years or so - increasing our total numbers by about a quarter. All of these new colleagues are not only legally qualified, but also have spent some years in legal practice. Because of them it is now much easier to see how a legal clinic could be staffed and supported at Cardiff; it fits within the new teaching parameters. These teaching developments are not exclusive to Cardiff. They have been replicated at other law schools in the UK, and provide the foundation upon which a resurgence in clinical legal education can take place.

\section{(c) Resources}

Although a number of universities now therefore have a pool of staff qualified to work in and give advice on clinical matters, it must appreciated

\footnotetext{
16 J. Macfarlane, "Look Before You Leap: Knowledge And Learning In Legal Skills Education" (1992) $19 \mathrm{~J}$ Law and Society 293 at p 297

17 See generally W. Twining, Blackstone's Tower: The English Law School (1994).
} 
that their participation cannot be on the basis of the high staff-student ratios traditionally encountered in lecture based courses. ${ }^{18}$ Although large group teaching can form part of the activities of clinical teachers, they are ultimately responsible for a series of cases each requiring individual attention. The students, in turn, must be individually supervised and given extensive feedback if the educational goals are to be achieved. Full secretarial and law office facilities are essential, as is the relevant insurance should things go wrong. Extra resources must therefore be allocated to the teaching and running of the clinic. This can be another cause of resentment for traditional academics who are less involved in skills teaching, and it is another reason why the support and involvement in the clinic of the law school as a whole is needed. It is also especially difficult to seek extra resources for teaching purposes when there has been undue emphasis in recent years on the quality of research produced.

Resources can be particularly stretched if the clinic operates an open door policy and attempts to deal with all cases which come in off the street. Invariably a free legal advice centre is soon overwhelmed with unmet legal need. The moral of both staff and students can then be badly affected by the pressures created by the high caseload, especially where it involves dealing in with what might be seen as identical problems. The clinic will therefore usually need to limit access in some way. For example, it may avoid those cases which are thought to be well dealt with by the local legal profession e.g. perhaps personal injury claims which can paid for on a conditional fee basis, or complex criminal matters where legal aid exists. Similarly, the directors of the clinic may need to ensure that it deals less with routine disputes, and that it instead focuses uponcases which involve wider matters of principle and which are better vehicles for achieving the educational objectives of the clinic. For example taking on a public law project or an important test case might be preferred to a series of minor consumer disputes.

\footnotetext{
${ }^{18}$ The Clinical Legal Education Organisation, Model Standards In Clinical Legal Education
} 
Another aspect of the resources issue is the number of students that can be accommodated within the clinical education programme. The opportunity to become involved in practice and deal with real clients makes work in the clinic an extremely popular option choice for students. It is therefore usually the case that the number of students admitted to the course has to be limited. How this is to be done can provoke dispute: are limits to be drawn by lottery, by grades, or by evidence of commitment ? This problem may also be encountered by other popular subjects in the law school curriculum, but it can be especially acute in the clinical context. Students may be aggrieved to find not only that the courses run in the law school are not available to all of the students all of the time, but also that some of them are never available other than to a chosen few.

\section{(d) Difficulties in supervision and assessment}

Supervising students in the clinic is subject to pressures which pull in opposite directions. Arriving at the right balance can be difficult. On the one hand the student learns best if left with as much control over a case as possible so that there is room to make mistakes, appreciate how thing may be done differently and change practice or behaviour accordingly. If 'learning by doing' is to be the leitmotif, it is no good looking over the student's shoulder all the time to correct what is being done. On the other hand, the obvious danger is that too much freedom will be given to the student and that this could result in a poor or even negligent service being provided to a client. The public could be used as guinea pigs on which the inexperienced experiment. It is therefore essential for a system of supervision to include checks on the quality of work being done e.g. the approval of all letters sent out, certain interviews recorded, file entries checked and diaries examined. It is also crucial that the supervisor be given sufficient knowledge of what the student has done in order to provide effective feedback and ensure that the clinical work forms part of the skills learning experience.

(1995) recommends that there be no more than twelve students to each member of staff. 
Another reason for ensuring that there is an appropriate level of supervision is in order for the law school to be able to make a formal assessment of the student's work. Obviously the traditional closed book three hour examination is a peculiarly inappropriate method of dealing with legal clinic work. Instead course work and some form of continuous assessment are employed. If these are well focused they can be a major element in the learning experience, and can provide clear goals to be achieved. Alternatively a simple pass/fail assessment of the work in the class can be made. If, however, there is no assessment at all, both the law school and the students will treat the clinical work as less important. It will then be much more difficult to achieve the educational goals outlined above. Attitudes towards assessment practices in the UK have changed greatly in recent years. Acceptance of these new practices is essential if clinical education is to thrive. ${ }^{19}$

\section{(e) The dangers of public service}

Although the idea of providing free legal advice is attractive to those who wish to see the university become more closely involved with the wider community in which it is based, problems can develop if the public service aim takes precedence over that of providing a sound and well rounded legal education. As already discussed, the clinic could become overwhelmed with clients and deal with routine problems which lack any wider legal focus or potential for lessons to be learned about the nature of law and legal practice.

However, it is not easy to draw a clear dividing line to limit the extent of the public service as opposed to educational benefits to students. ${ }^{20}$ It is true that clients can be turned away - although this is often something students find hard to do. But if the case has already been taken on then the duty to the

\footnotetext{
${ }^{19}$ For an analysis of methods of skills assessment see M. Maugham "A Capability Approach To Assessing Skills On The LPC" in J. Webb and C. Maugham (eds.), Teaching Lawyers' Skills (1996) at p 377, L. Lundy, "Assessment Of Clinical Legal Education: An Illustration" (1995) 29 Law Teacher 311, and H. Brayne et al, Clinical Legal Education (1998) pp 54-62 and 106-116.

20 K. Kerrigan and P. Plowden, "Who Benefits? - Case Management And Clinical Legal Education" (1996) 30 Law Teacher 315.
} 
client requires that the existing file must continue to be serviced even during student vacations or examination periods. Again resources, effective supervision and an efficient office system are needed to ensure that the interests of both students and clients are met. ${ }^{21}$

\section{(f) Relationship with the local legal profession}

Some may fear that a legal clinic offering free legal work will upset the law school's relation with the local legal profession. However, far from reducing the amount of work done by local practitioners, the clinic is likely to expand it. This is because it stimulates resort to the law, and the need for advice is increased out of proportion to the clinic's ability to deal with it. A referral system to local firms for certain types of advice or assistance is essential, and the number of people thus sent to lawyers far outweighs the work taken on by the clinic and which otherwise would have been dealt with a law firm. Far from being a source of friction, the clinic helps to foster a closer relationship with the local legal profession.

\section{THE DEVELOPMENT OF CLINICAL EDUCATION IN THE UK}

The idea of clinical legal education is not new. Northwestern Law School in Chicago has one of the oldest of the legal clinics, it being first established in $1910 .^{22}$ In the USA clinics were set up partly because of the absence of a formal trainee or apprenticeship position within the legal profession. ${ }^{23}$ Students are admitted to practice immediately on passing the bar exams. In spite of there being old examples, clinical education as recognised today in the USA really began in the 1960's. It spread rapidly. By 1973 of the 147 US

\footnotetext{
21 The duties of the clinic to the client are clearly laid out in The Clinical Legal Education Organisation, Model Standards In Clinical Legal Education (1995).

22 J. Rahl and K. Schwerin, Northwestern School Of Law - A Short History (1960) p. 28.

23 R. Stevens, Law School: Legal Education In America From The 1850's To The 1980's (1983) p 214.
} 
Law Schools 125 reported having some form of clinical education. ${ }^{24}$ Many of these benefited from Ford Foundation monies on condition that they supplied free poverty law advice. These monies came to an end in 1979, and this led to a re-evaluation and re-orientation of the American programmes.

In Britain the development of clinical education was much slower, and was not bankrolled by special funding. By 1994, in spite of all the problems of locating such education within the traditional university framework, 13 per cent of universities made use of live-client clinics. ${ }^{25}$ In the last five years two sets of factors have combined to produce increasing incentives for UK law schools to develop more clinical programmes:-

Firstly, in 1993 the Law Society gave up its direct control over the vocational stage of education and allowed the universities themselves to set up their own skills courses - their fourth year of teaching law - if they so wished. Cardiff has been in the vanguard. We soon appointed a number of practitioners to teach the skills courses, and the programme has operated with great success for six years now. The involvement of former law practitioners at Cardiff and other universities has led to an increasing interest in how and why legal education is being delivered. There has been a steady rise in the literature dealing with legal education, including articles on e.g. methods for delivering the skills curriculum. An umbrella organisation - the Clinical Legal Education Organisation - has been set up to disseminate information about clinical courses.

The second set of factors are of very recent origin. They relate to the increased possibility of gaining funds from outside the university in order to set up clinical programmes. There are at least two distinct sources:-

(a) The state - The Lord Chancellor has announced a community legal services initiative which is aimed at making legal advice and assistance more

\footnotetext{
${ }^{24}$ M. Zander, "Clinical Legal Education” [1973] New L J 181.

${ }^{25}$ R. Grimes, "Legal Skills And Clinical Legal Education" (1995) 2 Web Journal of Current Legal Issues and (1996) 30 Law Teacher 45.
} 
readily available. There is to be national funding for law centres which are to be set up in fifty regions throughout the UK. In so far as university legal clinics might be able to help meet these government objectives with regard to legal aid, they could become eligible for this state assistance. In Cardiff one such centre has just been launched (November 5 1999). As yet it has no links with the law school, but these are very early days.

(b) Large law firms - in 1997 a number of large firms, mostly based in the City of London, came together to set up the Solicitors Pro Bono Group. This charitable national organisation provides a co-ordinated response to legal need by working with the legal profession to set up new initiatives where free or reduced cost legal advice can be provided. Again very recently (October 25 1999 ) it was announced that this organisation in association with the largest skills provider - the College of Law - would set up free legal advice clinics at the branches of its College based in London, Guildford, Chester and York. The clinics are to be staffed by students receiving their fourth year of legal education. Most significantly the next stage is to create a national clinic advice centre, where university law schools can obtain funding and advice about how their students can obtain clinical training. Manchester University law school has agreed to be the pilot university for this part of the project. In the next five years it is intended that all major law schools should become involved. In providing financial help for this project one city law firm commented:

"We have been looking at how to embed the culture of pro bono work nationally. Using law schools is an imaginative idea. it builds into young lawyers' education a sense of community service and will give trainees coming to the firm like ours a much better preparation for practice." 26

\section{CONCLUSION}

Clinical legal education has a relatively long history, but it has yet to make a much of an impression on law schools in the UK. However, there is now

26 The Times, 25 October 1999, 
good reason to believe that it will begin to do so:-

- University law teachers are now more receptive to the teaching of legal skills. They recognise the educational value of importing such skills into many courses, including those in the traditional curriculum.

- There is now much more practical legal expertise in law schools upon which a clinic more firmly can be founded and continued support given.

- There are new sources of finance for clinical legal education and there are particular initiatives in both the public and private spheres which encourage the development of such programmes.

However, the relevance of these developments must not be confined only to those interested in what may happen in the UK. This article raises fundamental questions about the future of legal education in other countries and, in particular, in Japan:

- Should the strict separation between theory and practice be maintained?

- Should law teachers continue to be isolated from the practical legal world?

- Can the nature of law be fully understood and taught without having some knowledge of how the legal system actually operates?

I suggest that the answers to all three of these questions should be "no." The divisions must be reduced. Clinical legal education can help bridge the gaps. Of course, it is by no means a complete or even a wide-ranging solution to the problems facing law schools and universities today; it can play but a small part. But it does provide an indication of one of the directions in which future developments might take place. In a microcosm, it encapsulates many of the difficult issues which legal educators in Japan and other countries now face. 